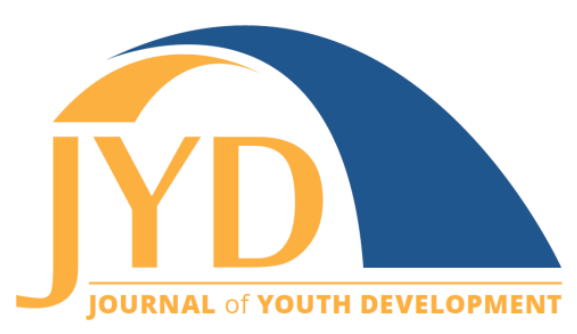

http://jyd.pitt.edu/ | Vol. 15 Issue 6 DOI 10.5195/jyd.2020.832 | ISSN 2325-4017 (online)

\title{
Enhancing College and Career Readiness Programs for Underserved Adolescents
}

\author{
Kevin A. Gee \\ School of Education, University of California, Davis \\ kagee@ucdavis.edu \\ Carolynne Beno \\ School of Education, University of California, Davis \\ ctbeno@ucdavis.edu

\section{Lauren Lindstrom} \\ School of Education, University of California, Davis \\ lelindstrom@ucdavis.edu
}

\section{John Lind}

College of Education, University of Oregon

jlind@uoregon.edu

\section{Cindy Post}

College of Education, University of Oregon

cpost3@uoregon.edu

\section{Kara Hirano}

College of Education, Illinois State University

kahira1@ilstu.edu

\begin{abstract}
Supporting college and career readiness among youth who encounter significant academic and life challenges requires innovative strategies to help them envision their futures, leverage their strengths and develop dispositions that promote positive trajectories. For youth development professionals who develop and implement novel programmatic approaches to support the college and career readiness of underserved youth, it is critical to acquire a deeper evidence-based understanding of factors shaping positive career and college pathways as well as to incorporate stakeholder viewpoints in their program design and delivery. In this article, we share key insights from our program development process that can inform the work of program developers, educators and youth services providers who seek to build
\end{abstract}

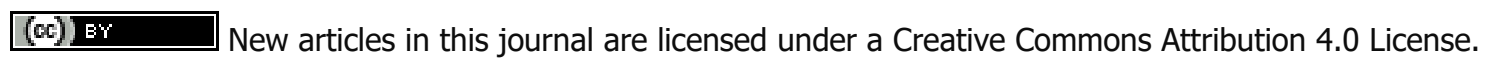
This journal is published by the University Library System, University of Pittsburgh and is cosponsored by the University of Pittsburgh Press. The Journal of Youth Development is the official peer-reviewed publication of the National Association of Extension 4-H Youth Development Professionals and the National AfterSchool Association. 


\section{Enhancing College and Career Readiness}

and enhance career and college readiness programs aimed at underserved youth. We summarize 4 key insights from a narrative review of literature on college and career readiness as well as findings from a set of stakeholders (student, parent and educator) focus groups. We offer our ideas for incorporating these insights alongside stakeholder input into the development and design of college and career readiness activities and programming.

Key words: college and career readiness, program development, adolescents, future selves

Adolescence is a critical developmental phase where many youth more fully explore who they are and their future aspirations (Nurmi, 1991). However, many underserved youth often confront sets of intersectional constraints that challenge their confidence in who they are and what they want to become (Oyserman \& Destin, 2010). For underserved youth who struggle in school-especially those with low academic performance, limited attendance, and a pattern of suspensions-their self-concept and ideas about the world of education and work may be constrained by individual, family, school or community contexts (Balfanz et al., 2007; Doll et al., 2013). Further intertwined with these challenges are broader societal challenges shaping their identities and futures, including structural inequalities that place many underserved youth and their families at a distinct socioeconomic disadvantage (Oyserman et al., 2011). In counterbalancing these constraints, interventions developed to promote positive pathways towards career and college (e.g., Oyserman et al., 2011) have strong potential to help youth development organizations re-envision how to promote college and career readiness while helping youth empower themselves by equipping them with the attitudes, behaviors and skills that are necessary towards envisioning and, ultimately, attaining their possible selves (Arnett, 2000; Markus \& Nurius, 1986; Oyserman et al., 2004).

However, there continues to be a need for robust models that provide sustained college and career planning (Venezia \& Jaeger, 2013), particularly models specifically targeting underserved adolescent groups. Certain underserved groups may especially benefit from college and career planning including students with disabilities (Morningstar et al., 2017) and adolescents who have had interactions with the juvenile justice system (Osborn \& Belle, 2018). In developing these models, it is important to ground models in the existing literature, both theoretical and empirical, as well as attend to the opinions and preferences of stakeholders served by such programs.

Accordingly, in this article, we distill key insights from selected literature alongside themes from focus groups with students, parents, teachers, and administrators about college and career readiness. Importantly, we offer ideas for incorporating these insights and themes into college and career readiness programming. In doing so, we believe our work can help inform the work 


\section{Enhancing College and Career Readiness}

of educators and youth services providers who seek to develop and enhance career and college readiness interventions aimed at underserved youth. These youth often fall outside mainstream college and career planning efforts. Also, we believe that insights from the literature and focus groups - both in our approach and substance-may be useful for organizations that are already serving this population but are seeking ways to refine and strengthen the content of their programs.

\section{Key Insights From A Narrative Review of the Literature}

To conduct our narrative review of the literature, we identified peer-reviewed literature-both theoretical and empirical-in three key areas related to college and career readiness: (a) selfawareness and its connection to students' future selves, (b) behavioral skills (e.g., communication and coping skills) promoting student persistence and success in education, and (c) career and college exploration for youth experiencing academic challenges and/or at-risk for school dropout. We established these three areas a priori given their importance in the design of existing college and career readiness curricula (e.g., Lindstrom et al., 2019). To conduct our literature search, we relied on standard academic search engines, including Google Scholar, Education Resources Information Center (ERIC) and journals in the field of education and career development. We used key search terms including career and college readiness, future selves, behavioral skills, student persistence, and adolescents. Where possible, we identified empirical studies that specifically included underserved youth in their study samples and were published primarily within the past 15 years (since 2004) with a few exceptions. In total, we identified 49 studies: 19 studies on self-awareness and future selves, 13 on behavioral skills, and 17 on career and college exploration. We provide information about each study (the citation, study description and sample) in Tables A1 (Self-Awareness and Future Selves), A2 (Behavioral Skills) and A3 (College and Career Readiness) in Appendix A.

Below we describe four key insights that emerged from our narrative review of the literature and suggest ways to operationalize these insights into college and career readiness programs. These insights emerged from a close review of each study and by noting a set of central ideas and commonalities across our selected studies that we felt were most salient particularly for youth from diverse backgrounds. 


\section{Enhancing College and Career Readiness}

\section{Developing Students' Future Selves via Stories}

Two central ideas from the career development literature are important when designing college and career readiness programs for adolescents. The first, drawn from Savickas's theory of career construction, emphasizes the critical role of generating personal stories in career development (Savickas, 2012). According to Savickas, individuals need to create personally constructed stories about who they are and what they want to become. He notes that "Stories constitute a critical element, because in addition to building a self, stories provide the efficient means through which an individual also builds a subjective career, that is, a story about his or her working life" (2012, p. 15). The second core idea is drawn from the literature on Future or Possible Selves (Oyserman et al., 2004). Achieving positive outcomes in both career and college relies on the importance of envisioning possible selves (Nurmi, 1991). Crafting a story helps individuals envision their future careers, linking their present selves to their future or possible selves.

Given the central role of story and its role in constructing individuals' future selves, we recommend engaging students in activities that have them construct their own stories. In contrast to Savickas, we suggest building activities that have students focus not only on stories about their future careers, but their futures more broadly, including future post-secondary educational aspirations. For example, one strategy is to have students generate stories about the experiences that shaped who they are now, known as their present selves (i.e., who they are today), and how their present selves link to their future selves (i.e., how they envision themselves in the future). One way do to this is by having students first discuss, in small groups, their histories and futures. Students can then formalize their discussions in a set of written responses about their life histories and futures that serve as small stories (Savickas, 2012). Through these smaller narratives, students can document personal events that have shaped who they are and aspirations of who they would like to become. These written artifacts allow students to construct and reconstruct their stories whose building blocks include narratives that students create about critical incidents and important figures in their lives (Savickas, 2012). Finally, students can synthesize elements of their discussion and written responses to generate a visual representation of their journey. Through this visual story mapping, students can depict who they want to become and the experiences that they need to engage in to obtain those experiences or to reach their goals.

Given that stories evolve, students should be encouraged to review, revisit and update their visual story maps at a later date. In doing so, they can more deeply reflect upon their maps alongside additional insights they have acquired about their strengths and interests which will 


\section{Enhancing College and Career Readiness}

inevitably shift over time. As student revisit their maps, an important concept to introduce to and emphasize with adolescents is career adaptability (Savickas, 1997), or the flexibility in skills and dispositions that individuals need to navigate multiple career transitions throughout the course of their career trajectories. This notion of adaptability can be reinforced as students discuss different career and college possibilities.

\section{Expanding Career and College Possibilities}

Though stories form a critical foundation for future selves, the narratives that underserved youth create about themselves and their futures may be constrained by images in popular media and textbooks, and expectations they see of themselves. Unfortunately, underserved youth often are exposed to deficit-based narratives of who they are (Pollack, 2012). To overcome these deficit perspectives, students need to expand and transform their sense of what is possible for them in the future (Rossiter, 2009). This requires them to be exposed to the widest range of possible selves in both career and college options.

To accomplish this, we suggest exposing students to a range of career options, including nontraditional careers. For example, students can learn to identify non-traditional careers and then determine whether there are non-traditional jobs that fit within their chosen interest areas. Career role models are also important, especially those with backgrounds and experiences that align with the students' own backgrounds. Social cognitive career theory suggests that role models can play a pivotal role in promoting career and educational aspirations (Karunanayake \& Nauta, 2004). Such models can not only promote positive character development (Johnson et al., 2016), but they can be especially critical for marginalized youth because strong role models can help individuals challenge their own deeply internalized stereotypes as well as act as exemplars for how to successfully navigate systemic discrimination in educational institutions and the workforce (Karunanayake \& Nauta, 2004). To expose students to role models, activities can be developed so that students are introduced to and network with community members who share similar backgrounds with the students. For example, we recommend that students have the chance to interact with, hear from and be mentored by more experienced youth who share their backgrounds, especially youth who may have attended and graduated from the same schools and have gone on to pursue career and college opportunities.

\section{Behavioral Strategies to Promote Success Among Underserved Youth}

Youth will commit sustained effort towards a possible self when there are behavioral strategies and social context supports to help them work on the possible self, when the possible self feels 


\section{Enhancing College and Career Readiness}

congruent with important social identities, and when difficulty working towards the possible self is normalized (Oyserman et al., 2006; Phalet, Andriessen, \& Lens, 2004; Yowell, 2002). This is particularly important for youth from certain underserved groups (e.g., youth from low income, rural or minority backgrounds), since these groups are more likely to display divergent aspirational and expected selves, and tend to have fewer academic or occupational possible selves (Oyserman \& Fryberg, 2006).

Importantly, these behavioral strategies can be operationalized as a set of navigational tools that can serve as a bridge between the stories that students generate about themselves and their futures and the procedural knowledge related to colleges and careers. Core behavioral strategies can include stress management, building resilience and goal setting. Research shows that students benefit from developing emotional regulation skills and learning how to manage stress (Gockel, 2015; Mendelson et al., 2010). Further, other studies have shown that students benefit from developing self-advocacy skills (Anctil et al., 2008; Milsom et al., 2004; Mishna et al., 2011), and self-determination skills (Sinclair et al., 2017).

Regarding social context supports, research shows that students' social environment can shape their views of their possible selves (Clinkinbeard \& Murray, 2012). Students' peers, families and teachers can provide crucial supports including positive feedback, validation, and encouragement. Together, these supports can help students build confidence thereby leading them to develop concrete strategies that they can enact to realize their possible selves. Given this, we suggest that college and career readiness programs incorporate activities that promote peer interaction and build community among students. For example, one key strategy that can be woven throughout any new or existing program is offering periodic, brief (10 minutes) and intentional check-in points that allow students to share their experiences with each other in either a large or small group setting. During this check-in time, students can share a dilemma, problem or achievement in their lives and then peers can offer ideas and feedback. One structure we recommend is first asking students who would like to share, then having students state their dilemma or problem in one to two sentences. Then, students decide the type of response they would like from their peers: (a) no response, just listen; (b) help me find options; or (c) advice needed. When paired with content related to generating stories and their future selves, this check-in time can offer students a unique opportunity to reflect on their own journeys of self-discoveries about who they are and what they aspire to become. 


\section{Enhancing College and Career Readiness}

\section{Emphasizing Strengths and Assets}

Career development literature indicates that vocational decisions are strongly influenced by how people view themselves (Leondari, 2007). During adolescence, youths' career aspirations and beliefs about their abilities predict their occupational attainment in adulthood (Schoon, 2001). Given the significant role of a person's self-view in career envisioning and attainment, it is important to help underserved adolescents focus on their unique strengths and assets, and to validate their funds of knowledge. Moll and colleagues (1992) define funds of knowledge as: "historically accumulated and culturally developed bodies of knowledge and skills essential for household or individual functioning and well-being" (p. 133). González and Moll (2002) demonstrated that when students investigate and document their numerous funds of knowledge, it can help them validate their identities.

To support underserved adolescents in exploring their funds of knowledge and discovering their distinct strengths, it is important for students to build self-awareness and self-understanding, learn to identify and utilize their personal strengths, and practice strategies to communicate these strengths effectively. As previously described, one of the central activities we recommend is having students create a visual map that helps students trace important life events and reflect on accomplishments and life experiences that have contributed to the formation of their identity. Through this activity, not only do students craft an overarching narrative about themselves and their futures, but students also use their funds of knowledge to define their self, which can help them transform their funds of knowledge into funds of identity (EstebanGuitart \& Moll, 2014). Funds of identity are the "historically accumulated, culturally developed, and socially distributed resources that are essential for a person's self-definition, selfexpression, and self-understanding" (Esteban-Guitart \& Moll, 2014, p. 31). By tapping into a students' funds of identity, the construction of their life stories and career maps helps them discover what they value, as well as where they want to go and how to go about getting there.

We also recommend that students be explicitly taught how to leverage their strengths to assist them in securing employment and applying for post-secondary education. For example, to distinguish their strengths, students can participate in a self-discovery activity where they identify positive experiences from their past (things they feel they did well, enjoyed doing, and are proud of). Students can then prioritize these experiences to identify their top positive experiences. Then, students can use a list of strength categories (e.g., helping, communication, educating/instructing, leading/managing, numbers/details, physical/manual, problem solving/research, and creative/artistic) to discern their personal strengths. Next, students practice talking about their identified strengths with the understanding that they need to be 


\section{Enhancing College and Career Readiness}

able to talk about their strengths in an authentic and compelling way for future job or school interviews.

\section{Stakeholder Perspectives on College and Career Readiness Programming}

To further inform the development of college and career readiness programming, we strongly believe that centralizing the voices and experiences of stakeholders, especially the students themselves, is critical. Thus, we conducted a series of focus groups to capture the opinions of students and parents who have been often marginalized from the career planning and development process. We spoke with a purposeful sample of youth, parents, and educators (teachers, school staff or school administrators) recruited from two high schools in California and four high schools in Oregon. We selected these sites because they serve high percentages of underserved students and had expressed interest in participating in a potential pilot implementation of a college and career readiness intervention. Participating youth in our focus groups experienced individual and family risk factors that significantly increased their likelihood of dropping out of school including (a) low school achievement, (b) retention/over age for grade, (c) poor school attendance, (d) pattern of behavior referrals/suspensions, (e) low family socioeconomic status, or (f) identified with a learning or emotional disability (Hammond et al., 2007).

At each school site, we conducted one student focus group, one parent focus group and one educator focus group, for a total of 18 focus groups. Our focus groups included 37 students, 18 parents and 48 educators, for a total $N=103$. Average focus group sizes were $n=6$ for students, $n=3$ for parents, and $n=8$ for educators. Appendix B describes key demographic characteristics of our student, parent and educator focus group participants across six schools.

We developed separate focus group protocols for students, parents and educators, and each protocol covered questions in three central areas: (a) barriers and facilitators that impact academic achievement and school engagement for high school youth facing academic challenges or dropout, (b) curricular components and activities that should be included in a college and career readiness program, and (c) potential implementation approaches for a college and career readiness program. Our focus groups were audio recorded and transcribed. We coded our focus group data using a two-stage approach (Miles et al., 2013). First, we developed a broad set of descriptive codes based on our initial review of the transcripts. Then we used descriptive codes, such as "strategies for college and career readiness" and "barriers to education and career outcomes" to assign concrete labels to individual passages of text. In the 


\section{Enhancing College and Career Readiness}

second phase of analyses, we used cross-case methods (Miles et al., 2013; Patton, 2014) to further describe and verify our findings. Our focus group findings provide helpful guidance to program developers in two key areas: (a) programmatic content and (b) preferred learning approaches, which are described below.

\section{Perspectives on Programmatic Content}

Through our focus groups, students, educators, and parents collectively identified five key topics essential to college and career readiness programming: (a) basic employability or "soft skills," (b) personal strengths, (c) mindfulness activities, (d) developing goals, and (e) career and college readiness skill building.

\section{Basic Employability or "Soft Skills"}

First, focus group participants thought that academic skills in isolation were not sufficient for career and college readiness. Instead, young people preparing for the future also need to demonstrate basic employability or "soft skills," often defined as a combination of people skills, social skills, communication skills, character or personality traits, and attitudes that enable people to navigate their environment and interact effectively with other people. One teacher remarked, "My thought is that not only do they have the academic skills but they also have the soft skills and that they're able to get along with others and they have skills to problem solve," while another noted, "One of the most important things for our youth is all the soft skills-how to communicate, how to have relationships, positive relationships with people, how to ask for help when needed." Other important soft skills and traits specifically identified by focus group participants included: advocacy, communication, coping, time management, adaptability, grit, persistence, and hope.

\section{Personal Strengths}

Second, focus group participants felt students need to not only understand their strengths, but also learn how to use them to develop their goals and future plans. One teacher shared, "I see a lot of kids who learn about their personal strengths, but they never figure out how to actually use their personal strengths to do something."

\section{Mindfulness Activities.}

Third, student focus group participants expressed an interest in exploring mindfulness activities, which might include deep breathing exercises, mindful walks, meditation, yoga, etc. One student shared his personal experience with mindfulness, "When I started meditating about a 


\section{Enhancing College and Career Readiness}

year back, I haven't done it as much as I used to in the last few months, but it changed my personality so much, and I didn't get angry at all." Similarly, teacher focus group participants validated student interest in mindfulness. One teacher shared, "They love it. I did start meditation every morning last semester and there was a lot of buy-in. . . . I think it was extremely helpful and I had a lot of kids very vocal about how grateful they were." Therefore, we recommend program developers consider ways to integrate mindful techniques into daily class activities.

\section{Developing Goals}

Fourth, focus group participants indicated students need to learn how to define and set realistic goals. A teacher shared, "You want to be a video game developer. Okay. That's a great goal. But what are all the little goals, steps that we need to take to get to that one? And is that viable?" To emphasize goal-setting, program developers may want to develop activities that help students construct goals using the SMART (specific, measurable, achievable/attainable, relevant, timely) approach. Furthermore, other participants cautioned that goal-setting alone is not enough. Instead, students need to be supported in developing a clear plan for transitioning into college and/or careers directly after high school. A student explained, "I guess you could say it would be helpful but not exactly setting goals because anybody can set a goal. It's more helping us achieve and helping us think of ways to achieve our goals would be more helpful."

\section{Career and College Readiness Skill Building}

Finally, focus group participants felt that college and career readiness also involved being able to demonstrate a number of career-related competencies and skills including both academic and employability skills. Educators and students both emphasized the importance of academic skills such as reading, writing, and study skills and the ability to apply those skills to complete required coursework and credits needed for high school graduation. A teacher reflected, "I think to start with we look for students who are well-rounded and complete a variety of tasks and courses at school. Obviously completing the required courses and the correct amount of credits." Study and organizational skills were also important to students. One noted that to be successful in college and careers, you need "to be able to plan when you're gonna do your homework, when to study and what time you have to go to school, or work."

In addition, student participants stressed the need to understand specific transition skills required to apply for both employment and college opportunities. Many students believed that to be ready for post-school opportunities, they needed specific instruction in skills such as writing a resume, applying and interviewing for jobs, and completing the process of applying for 


\section{Enhancing College and Career Readiness}

financial aid or scholarships to attend college. Considering the prospect of finding employment, one student said, "I think that creating your own resume from stuff you have actually done would be helpful, . . . and then in addition just tips on what to do, like how to get an interview." Since focus group participants highlighted the importance of career and college skill building activities (e.g., career and college exploration, interviewing, resume writing, etc.), programs should offer students opportunities to build critical skills to promote job and college success and embed them within more traditional career and college exploration activities.

\section{Perspectives on Preferred Learning Approaches}

Our focus group feedback not only highlighted substantive content that students, teachers and parents preferred in a college and career readiness program, but also highlighted the types of activities and instructional approaches all three groups preferred. For instance, focus group participants universally recommended that experiential learning was highly valuable for college and career exploration, awareness, and visioning. Several parent participants specifically cited career technical education as contributing to successful post-school career opportunities, noting that "Because of that welding class, he is very successful, and it all comes down to that welding class. It was important to him. . . . and then he had somebody in town here give him a chance in their shop." Another family member remembered that their child "went through the automotive program and he was really excellent, and he really loved it and he figured out his brain is wired to do those kinds of things."

Other career-related opportunities suggested during focus groups included: field trips to local businesses, college tours, career inventories, career-related clubs, and guest speakers representing various careers. All of these career-related learning activities exposed youth to a range of career pathways and potentially inspired them to expand aspirations. A teacher remembered that, "I think it's important that we have guest speakers who . . . traveled down the same road that they've traveled and become successful. There's been a couple times when we had college students who have been in juvenile hall or even been in prison and have come back and spoken with our students and they've said, 'Wow, if they can do it, I can do it."'

Focus group participants identified career-related learning along with guidance and support from trusted adults as key elements that can shape and influence career and college readiness for underserved youth. As one educator remarked, "Anytime you offer them something that has a road out of high school that's realistic and something they can understand, and get their teeth sunk into, so to speak, they're very interested in that." A parent also focused on future options 


\section{Enhancing College and Career Readiness}

for her son despite previous struggles and challenges in school. "And that's why I have such high hopes. . . . He's still capable of having his own version of success and being a productive member of society and everything leading up to this point has taught him to the contrary." Hence, we recommend that programs consider incorporating interactive student-centered learning approaches, including guest speakers, field trips to businesses and work sites, a college or university campus visit, a college student panel, and mock interviews.

\section{Guidance for Youth Development Professionals}

In synthesizing themes from our literature review and focus groups, we offer three key recommendations for how youth development practitioners can use our findings to guide and inform practice.

First, in addition to helping youth develop the "hard" skills of college and career planning (e.g., filling out applications and preparing required materials), programs should provide rich and varied opportunities for students to develop and practice behaviors integral in helping underserved youth build their confidence. For instance, themes from both the literature review and focus groups centered on the notion of helping youth develop personal strengths, and providing opportunities for them to practice strategies to communicate these strengths effectively in work and post-secondary educational settings. Not only were strengths relevant, but also the behaviors and dispositions important to navigating their career and college experiences-especially the soft skills including social and communication skills necessary to interact effectively with people.

Second, as we found through our focus groups, practitioners themselves alongside parents felt that helping students set goals is important when engaging them in thinking about careers and college. Practically, as we suggest, introducing students to how to develop goals using a SMART approach is one way to do this. Beyond the importance of goal-setting in and of itself, when considered with our literature review findings on future selves, we recommend that goal-setting attached to career and college aspirations should also be interwoven through a series of activities by which students construct meaningful stories of who they are and who they want to become; importantly, these stories of their future or possible selves, can be informed by sets of written activities that are then formalized onto visual maps. Further, when helping youth establish career and college goals, it is critical to first expose them to as many different possibilities of what they can aspire to become that are congruent with their own social identities. 


\section{Enhancing College and Career Readiness}

Finally, any college and career readiness program needs to be supported by active learning strategies that are student-centered. As we found in our focus groups, not only are active approaches preferred over passive or direct instruction methods, but our review of the literature highlighted the importance of leveraging students' funds of knowledge-or the culturally relevant knowledge and assets they bring into the learning environments. Using active learning methods (e.g., experiential learning) combined with their funds of knowledge can help deepen their engagement in activities and programs aimed at promoting college and career readiness.

\section{Conclusion}

Providing robust college and career readiness programming-informed by the literature and stakeholder perspectives - can offer youth novel opportunities to develop a clearer sense of future opportunities for their success. By introducing underserved youth to content (e.g. career and college options) and providing opportunities to practice new skills and behaviors (e.g., communication, problem solving, coping skills), we hope that students who have been traditionally underserved in college and career planning efforts can fulfill their college and career aspirations. Our study identified several topics that may not be present in traditional college and career readiness programming (e.g., exposure to a broad range of possible selves, constructing personal stories, mindfulness, leveraging personal strengths, grit, adaptability, etc.), which we believe all students, and particularly underserved students, would benefit from explicit instruction in. Our study further recognized innovative strategies teachers can use to facilitate learning opportunities (e.g., experiential learning, interactive activities, etc.). Finally, more broadly, the themes we have gleaned from both the literature alongside stakeholder perspectives reviewed in this article can raise critical awareness among key stakeholders, including youth program developers, of the skills, attitudes and knowledge that underserved youth need as they plan and prepare for their careers and post-secondary educational pathways.

\section{Acknowledgements}

This study was supported by the Institute for Education Sciences (IES), U.S. Department of Education, through grant R305A170633. The authors would like to thank Tseng Vang for his assistance with preparing this article. 
Journal of Youth Development | http://jyd.pitt.edu/ | Vol. 15 Issue 6 DOI 10.5195/jyd.2020.832 Enhancing College and Career Readiness

\section{References}

Anctil, T. M., Ishikawa, M. E., \& Tao Scott, A. (2008). Academic identity development through selfdetermination. Career Development for Exceptional Individuals, 31(3), 164-174. https://doi.org/10.1177/0885728808315331

Arnett, J. J. (2000). Emerging adulthood: A theory of development from the late teens through the twenties. American Psychologist, 55(5), 469. https://doi.org/10.1037//0003-066x.55.5.469

Balfanz, R., Herzog, L., \& Mac Iver, D. J. (2007). Preventing student disengagement and keeping students on the graduation path in urban middle-grades schools: Early identification and effective interventions. Educational Psychologist, 42(4), 223-235.

\section{https://doi.org/10.1080/00461520701621079}

Clinkinbeard, S. S., \& Murray, C. I. (2012). Perceived support, belonging, and possible selves strategies among incarcerated juvenile offenders. Journal of Applied Social Psychology, 42(5), 1218-1240. 10.1111/j.1559-1816.2011.00884.x

Doll, J. J., Eslami, Z., \& Walters, L. (2013). Understanding why students drop out of high school, according to their own reports: Are they pushed or pulled, or do they fall out? A comparative analysis of seven nationally representative studies. SAGE Open, 3(4), 1-15.

\section{https://doi.org/10.1177/2158244013503834}

Esteban-Guitart, M., \& Moll, L. C. (2014). Funds of identity: A new concept based on the funds of knowledge approach. Culture \& Psychology, 20(1), 31-48.

\section{https://doi.org/10.1177/1354067X13515934}

Gockel, A. (2015). Teaching note-practicing presence: A curriculum for integrating mindfulness training into direct practice instruction. Journal of Social Work Education, 51(4), 682-690. https://doi.org/10.1080/10437797.2015.1076275

González, N., \& Moll, L. C. (2002). Cruzando el puente: Building bridges to funds of knowledge. Educational Policy, 16(4), 623-641. https://doi.org/10.1177/0895904802016004009

Hammond, C., Linton, D., Smink, J., \& Drew, S. (2007). Dropout risk factors and exemplary programs: $A$ technical report. National Dropout Prevention Center/Network. Anderson, South Carolina.

Johnson, S. K., Buckingham, M. H., Morris, S. L., Suzuki, S., Weiner, M. B., Hershberg, R. M., . . Hunter, C. J. (2016). Adolescents' character role models: Exploring who young people look up to as examples of how to be a good person. Research in Human Development, 13(2), 126-141.

Karunanayake, D., \& Nauta, M. M. (2004). The relationship between race and students' identified career role models and perceived role model influence. The Career Development Quarterly, 52(3), 225234. https://doi.org/10.1002/j.2161-0045.2004.tb00644.x

Leondari, A. (2007). Future time perspective, possible selves, and academic achievement. New Directions for Adult and Continuing Education, 2007114), 17-26. https://doi.org/10.1002/ace.253 
Journal of Youth Development | http://jyd.pitt.edu/ | Vol. 15 Issue 6 DOI 10.5195/jyd.2020.832 Enhancing College and Career Readiness

Lindstrom, L., Hirano, K. A., Ingram, A., DeGarmo, D. S., \& Post, C. (2019). "Learning to be myself": Paths 2 the future career development curriculum for young women with disabilities. Journal of Career Development, 46(4), 469-483. https://doi.org/10.1177/0894845318776795

Markus, H., \& Nurius, P. (1986). Possible selves. American Psychologist, 41(9), 954-969. https://doi.org/10.1037/0003-066X.41.9.954

Mendelson, T., Greenberg, M. T., Dariotis, J. K., Gould, L. F., Rhoades, B. L., \& Leaf, P. J. (2010). Feasibility and preliminary outcomes of a school-based mindfulness intervention for urban youth. Journal of Abnormal Child Psychology, 38(7), 985-994. https://doi.org/10.1007/s10802-010$\underline{9418-x}$

Miles, M. B., Huberman, A. M., \& Saldana, J. (2013). Qualitative data analysis: A methods sourcebook. SAGE.

Milsom, A., Akos, P., \& Thompson, M. (2004). A psychoeducational group approach to postsecondary transition planning for students with learning disabilities. The Journal for Specialists in Group Work, 29(4), 395-411. https://doi.org/10.1080/01933920490516170

Mishna, F., Muskat, B., Farnia, F., \& Wiener, J. (2011). The effects of a school-based program on the reported self-advocacy knowledge of students with learning disabilities. Alberta Journal of Educational Research, 57(2), 185-203.

Moll, L. C., Amanti, C., Neff, D., \& Gonzalez, N. (1992). Funds of knowledge for teaching: Using a qualitative approach to connect homes and classrooms. Theory Into Practice, 31(2), 132-141. https://doi.org/10.1080/00405849209543534

Morningstar, M. E., Lombardi, A., Fowler, C. H., \& Test, D. W. (2017). A college and career readiness framework for secondary students with disabilities. Career Development and Transition for Exceptional Individuals, 40(2), 79-91. https://doi.org/10.1177\%2F2165143415589926

Nurmi, J.-E. (1991). How do adolescents see their future? A review of the development of future orientation and planning. Developmental Review, 11(1), 1-59. https://doi.org/10.1016/02732297(91)90002-6

Osborn, D. S., \& Belle, J. G. (2018). Preparing juvenile offenders for college and career readiness: A cognitive information processing approach. Journal of Educational and Psychological Consultation, 1-31. https://doi.org/10.1080/10474412.2018.1482216

Oyserman, D., Bybee, D., \& Terry, K. (2006). Possible selves and academic outcomes: How and when possible selves impel action. Journal of Personality and Social Psychology, 91(1), 188-204. https://doi.org/10.1037/0022-3514.91.1.188

Oyserman, D., Bybee, D., Terry, K., \& Hart-Johnson, T. (2004). Possible selves as roadmaps. Journal of Research in Personality, 38(2), 130-149. https://doi.org/10.1016/S0092-6566(03)00057-6

Oyserman, D., \& Destin, M. (2010). Identity-based motivation: Implications for intervention. The Counseling Psychologist, 38(7), 1001-1043. https://doi.org/10.1177/0011000010374775 
Journal of Youth Development | http://jyd.pitt.edu/ | Vol. 15 Issue 6 DOI 10.5195/jyd.2020.832

\section{Enhancing College and Career Readiness}

Oyserman, D., \& Fryberg, S. (2006). The possible selves of diverse adolescents: Content and function across gender, race and national origin. In C. D. J. Kerpelman (Ed.), Possible selves: Theory, research, and applications (pp. 17-39). Nova Science Publishers.

Oyserman, D., Johnson, E., \& James, L. (2011). Seeing the destination but not the path: Effects of socioeconomic disadvantage on school-focused possible self content and linked behavioral strategies. Self and Identity: The Journal of the International Society for Self and Identity, 10(4), 474-492. https://doi.org/10.1080/15298868.2010.487651

Patton, M. Q. (2014). Qualitative research \& evaluation methods : Integrating theory and practice. SAGE.

Phalet, K., Andriessen, I., \& Lens, W. (2004). How future goals enhance motivation and learning in multicultural classrooms. Educational Psychology Review, 16(1), 59-89.

\section{https://doi.org/10.1023/B:EDPR.0000012345.71645.d4}

Pollack, T. M. (2012). The miseducation of a beginning teacher: One educator's critical reflections on the functions and power of deficit narratives. Multicultural Perspectives, 14(2), 93-98.

\section{https://doi.org/10.1080/15210960.2012.673318}

Rossiter, M. (2009). Possible selves and career transition: Implications for serving nontraditional students. The Journal of Continuing Higher Education, 57(2), 61-71. https://doi.org/10.1080/07377360902991858

Savickas, M. L. (1997). Career adaptability: An integrative construct for life-span, life-space theory. The Career Development Quarterly, 45(3), 247-259. https://doi.org/10.1002/j.21610045.1997.tb00469.x

Savickas, M. L. (2012). Life design: A paradigm for career intervention in the $21^{\text {st }}$ century. Journal of Counseling \& Development, 90(1), 13-19. https://doi.org/10.1111/j.1556-6676.2012.00002.x

Schoon, I. (2001). Teenage job aspirations and career attainment in adulthood: A 17-year follow-up study of teenagers who aspired to become scientists, health professionals, or engineers. International Journal of Behavioral Development, 25(2), 124-132. https://doi.org/10.1080/01650250042000186

Sinclair, J., Bromley, K. W., Shogren, K. A., Murray, C., Unruh, D. K., \& Harn, B. A. (2017). An analysis of motivation in three self-determination curricula. Career Development and Transition for Exceptional Individuals, 4O(3), 175-185. https://doi.org/10.1177/2165143416676081

Venezia, A., \& Jaeger, L. (2013). Transitions from high school to college. The Future of Children, 117136.

Yowell, C. M. (2002). Dreams of the future: The pursuit of education and career possible selves among ninth grade latino youth. Applied Developmental Science, 6(2), 62-72. https://doi.org/10.1207/S1532480XADS0602 2 


\section{Appendix A}

\section{Literature Search Results: Studies Related to College and Career Readiness}

Table A1. Peer-Reviewed Literature on Self-Awareness and Future Selves $(n=19)$

\begin{tabular}{|c|c|c|}
\hline Article & Study description & Sample \\
\hline \multicolumn{3}{|c|}{ LITERATURE DESCRIBING POSSIBLE SELVES } \\
\hline $\begin{array}{l}\text { Markus, H., \& Nurius, P. (1986). } \\
\text { Possible selves. American } \\
\text { Psychologist, 41(9), } 954 .\end{array}$ & $\begin{array}{l}\text { The article examined the theoretical } \\
\text { features of possible selves and } \\
\text { illustrated how they may mediate } \\
\text { personal functioning. }\end{array}$ & $\mathrm{N} / \mathrm{A}$ \\
\hline $\begin{array}{l}\text { Oyserman, D., Bybee, D., Terry, K., } \\
\text { \& Hart-Johnson, T. (2004). Possible } \\
\text { selves as roadmaps. Journal of } \\
\text { Research in Personality, 38(2), 130- } \\
149 .\end{array}$ & $\begin{array}{l}\text { The authors hypothesized that } \\
\text { improved academic outcomes were } \\
\text { likely only when a possible self } \\
\text { could plausibly be a self-regulator. }\end{array}$ & $\begin{array}{l}160 \text { low income eighth graders from } \\
\text { three inner city middle schools } \\
\text { serving low-income families ( } 67.3 \% \\
\text { of students at the schools received } \\
\text { free or reduced-price lunch). }\end{array}$ \\
\hline $\begin{array}{l}\text { Anderman, E. M., Anderman, L. H., } \\
\text { \& Griesinger, T. (1999). The relation } \\
\text { of present and possible academic } \\
\text { selves during early adolescence to } \\
\text { grade point average and } \\
\text { achievement goals. The Elementary } \\
\text { School Journal, } 100(1), 3-17 \text {. }\end{array}$ & $\begin{array}{l}\text { This article describes } 2 \text { studies } \\
\text { examining the role of present and } \\
\text { possible (future) academic } \\
\text { selves. }\end{array}$ & $\begin{array}{l}\text { In the first study survey data were } \\
\text { collected from a sample of } 315 \\
\text { seventh-grade students. } \\
\text { In the second study, survey data } \\
\text { were collected from a different } \\
\text { sample of } 220 \text { sixth, seventh, and } \\
\text { eighth graders. }\end{array}$ \\
\hline \multicolumn{3}{|c|}{ LITERATURE DESCRIBING POSSIBLE SELVES OF DIVERSE ADOLESCENTS } \\
\hline $\begin{array}{l}\text { Oyserman, D., \& Fryberg, S. (2006). } \\
\text { The possible selves of diverse } \\
\text { adolescents: Content and function } \\
\text { across gender, race and national } \\
\text { origin. Possible selves: Theory, } \\
\text { research and applications. (pp. 17- } \\
\text { 39). Hauppauge, NY, US: Nova } \\
\text { Science Publishers. }\end{array}$ & $\begin{array}{l}\text { This chapter is part of a book that } \\
\text { discusses possible selves and } \\
\text { implications of possible selves for } \\
\text { male/female adolescent outcomes } \\
\text { through a lens of race/ethnicity } \\
\text { (i.e., African American, Asian } \\
\text { American, Latino, Native American, } \\
\text { and white). }\end{array}$ & $\mathrm{N} / \mathrm{A}$ \\
\hline $\begin{array}{l}\text { Day, J. D., Borkowski, J. G., Punzo, } \\
\text { D., \& Howsepian, B. (1994). } \\
\text { Enhancing possible selves in }\end{array}$ & $\begin{array}{l}\text { This study focused Mexican- } \\
\text { American students' views about } \\
\text { their learning potential and how }\end{array}$ & $\begin{array}{l}83 \text { Mexican American children } \\
\text { participated in the study: } 30 \text { third } \\
\text { graders, } 31 \text { fourth graders, and } 22\end{array}$ \\
\hline
\end{tabular}




\section{Enhancing College and Career Readiness}

\begin{tabular}{|c|c|c|}
\hline $\begin{array}{l}\text { Mexican American students. } \\
\text { Motivation and Emotion, 18(1), 79- } \\
103 .\end{array}$ & $\begin{array}{l}\text { they made meaning between the } \\
\text { links between their present school } \\
\text { performance and their futures. }\end{array}$ & $\begin{array}{l}\text { fifth graders. Fourteen children } \\
\text { were in a no-instruction control } \\
\text { group, } 43 \text { were in the child-only } \\
\text { intervention group, and } 26 \text { were in } \\
\text { the combined parent and child } \\
\text { condition. Children completed pre- } \\
\text { and post-intervention } \\
\text { questionnaires. }\end{array}$ \\
\hline $\begin{array}{l}\text { Kerpelman, J. L., Shoffner, M. F., \& } \\
\text { Ross-Griffin, S. (2002). African } \\
\text { American mothers' and daughters' } \\
\text { beliefs about possible selves and } \\
\text { their strategies for reaching the } \\
\text { adolescents' future academic and } \\
\text { career goals. Journal of Youth and } \\
\text { Adolescence, 31(4), 289-302. }\end{array}$ & $\begin{array}{l}\text { The current study combines } \\
\text { qualitative and quantitative data to } \\
\text { examine beliefs and strategies } \\
\text { related to possible selves. }\end{array}$ & $\begin{array}{l}22 \text { rural African American female } \\
\text { adolescents and their mothers. }\end{array}$ \\
\hline $\begin{array}{l}\text { Yowell, C. M. (2002). Dreams of the } \\
\text { future: The pursuit of education and } \\
\text { career possible selves among ninth } \\
\text { grade Latino youth. Applied } \\
\text { Developmental Science, 6(2),62- } \\
72 .\end{array}$ & $\begin{array}{l}\text { This study explored the relationship } \\
\text { between Latino students' } \\
\text { conceptions of their futures and } \\
\text { their risk status for school dropout. }\end{array}$ & $4159^{\text {th }}$ grade Latino students. \\
\hline $\begin{array}{l}\text { Leondari, A. (2007). Future time } \\
\text { perspective, possible selves, and } \\
\text { academic achievement. New } \\
\text { Directions for Adult and Continuing } \\
\text { Education, } 2007 \text { (114), 17-26. }\end{array}$ & $\begin{array}{l}\text { This chapter reviews literature that } \\
\text { outlines the concept of future time } \\
\text { perspective (FTP) as it relates to } \\
\text { possible selves and academic } \\
\text { performance. }\end{array}$ & N/A \\
\hline \multicolumn{3}{|c|}{ LITERATURE DESCRIBING PATHWAYS TO SUCCESS THROUGH IDENTITY-BASED MOTIVATION (IBM) } \\
\hline $\begin{array}{l}\text { Oyserman, D., \& Destin, M. (2010). } \\
\text { Identity-based motivation: } \\
\text { Implications for intervention. The } \\
\text { Counseling Psychologist, 38(7), } \\
\text { 1001-1043. }\end{array}$ & $\begin{array}{l}\text { This article outlines and tests } \\
\text { whether children's perceptions of } \\
\text { what is possible for them influence } \\
\text { the aspiration-attainment gap using } \\
\text { a culturally sensitive framework } \\
\text { called identity-based motivation } \\
\text { (IBM; Oyserman, 2007, 2009). }\end{array}$ & $\begin{array}{l}\text { Study } 1 \text { included eighth graders } \\
\text { from three Detroit middle schools ( } n \\
=266,72 \% \text { African American, } 17 \% \\
\text { Latino, } 11 \% \text { White) serving high } \\
\text { poverty. } \\
\text { Study } 2 \text { included seventh-grade } \\
\text { children ( } n=295 \text {, African American }\end{array}$ \\
\hline
\end{tabular}




\section{Enhancing College and Career Readiness}

\begin{tabular}{|c|c|c|}
\hline & & $\begin{array}{l}57 \% \text {, White } 29 \% \text {, Biracial/Other/No } \\
\text { response } 12 \% \text {, Latino } 2 \% \text { ) in a } \\
\text { Detroit-area middle school. }\end{array}$ \\
\hline $\begin{array}{l}\text { Oyserman, D., Terry, K., \& Bybee, } \\
\text { D. (2002). A possible selves } \\
\text { intervention to enhance school } \\
\text { involvement. Journal of } \\
\text { Adolescence, 25(3), 313-326. }\end{array}$ & $\begin{array}{l}\text { This article explained the School-to- } \\
\text { Jobs intervention and highlighted } \\
\text { the results. }\end{array}$ & $\begin{array}{l}62 \text { African American inner city } \\
\text { middle school students in schools } \\
\text { where over } 90 \% \text { of students were } \\
\text { eligible for free or reduced lunch, } \\
\text { and students lived in neighborhoods } \\
\text { with over } 40 \% \text { of families living in } \\
\text { poverty. }\end{array}$ \\
\hline
\end{tabular}

\section{LITERATURE DESCRIBING ACADEMIC POSSIBLE SELVES}

Oyserman, D., Bybee, D., \& Terry,

K. (2006). Possible selves and academic outcomes: How and when possible selves impel action. Journal of Personality and Social Psychology, 91(1), 188.
The authors hypothesized that

simply having academic possible

selves are not enough unless linked

with plausible strategies, made to

feel like "true" selves, and

connected with social identity.
Data were collected from three Detroit middle schools. $71.6 \%$ of students were African American, $17.4 \%$ were Latino, and $11 \%$ were white. Two-thirds of students received free or reduced-price lunch, and only $43.3 \%$ of adults were employed. A random assignment of participants was used during the elective hour.

239 students in the first semester of ninth grade ( $91 \%$ of the total randomized sample; $n=131$ experimental, $n=108$ control; $n=$ 127 girls, $n=112$ boys; $n=179$ African American, $n=41$ Latino, and $n=19$ White).

\section{LITERATURE DESCRIBING STRENTHS FINDER/IDENTIFICATION; VOCATIONAL SELF-EFFICACY}

Cleary, T. J., \& Zimmerman, B. J.

(2004). Self-regulation

empowerment program: A school-

based program to enhance selfregulated and self-motivated cycles of student learning. Psychology in the Schools, 41(5), 537-550.
This article describes a training program, Self-Regulation

Empowerment Program (SREP),

that was developed out of socialcognitive theory. It was designed to empower adolescent students to "engage in more positive, self-
The SREP has been pilot tested with a variety of middle-school students in a suburban school district. This article described the case studies, which were not experimental in nature. 


\section{Enhancing College and Career Readiness}

\begin{tabular}{|c|c|c|}
\hline & motivating cycles of learning." & \\
\hline $\begin{array}{l}\text { Kerpelman, J. L., Eryigit, S., \& } \\
\text { Stephens, C. J. (2008). African } \\
\text { American adolescents' future } \\
\text { education orientation: Associations } \\
\text { with self-efficacy, ethnic identity, } \\
\text { and perceived parental support. } \\
\text { Journal of Youth and Adolescence, } \\
\text { 37(8), 997-1008. }\end{array}$ & $\begin{array}{l}\text { This study investigated the } \\
\text { associations of self-efficacy, ethnic } \\
\text { identity and parental support with } \\
\text { "future education orientation" } \\
\text { among African American students. }\end{array}$ & $\begin{array}{l}374 \text { African American students } \\
\text { (59.4\% female) in grades } 7-12 \\
\text { attending a rural, southern county } \\
\text { public school participated in the } \\
\text { study. }\end{array}$ \\
\hline $\begin{array}{l}\text { Ali, S. R., McWhirter, E. H., \& } \\
\text { Chronister, K. M. (2005). Self- } \\
\text { efficacy and vocational outcome } \\
\text { expectations for adolescents of } \\
\text { lower socioeconomic status: A pilot } \\
\text { study. Journal of Career } \\
\text { Assessment, 13(1), 40-58. }\end{array}$ & $\begin{array}{l}\text { This exploratory study investigated } \\
\text { the relationships between } \\
\text { contextual support, perceived } \\
\text { educational barriers, and } \\
\text { vocational/educational self-efficacy } \\
\text { and outcome expectations. }\end{array}$ & $\begin{array}{l}114 \text { ninth graders from lower } \\
\text { socioeconomic backgrounds. }\end{array}$ \\
\hline $\begin{array}{l}\text { McWhirter, E. H., Crothers, M., \& } \\
\text { Rasheed, S. (2000). The effects of } \\
\text { high school career education on } \\
\text { social-cognitive variables. Journal of } \\
\text { Counseling Psychology, 47(3), } 330 .\end{array}$ & $\begin{array}{l}\text { This study investigated the } \\
\text { influence of a 9-week career } \\
\text { education class on career decision- } \\
\text { making self-efficacy, vocational } \\
\text { skills self-efficacy, perceived } \\
\text { educational barriers, outcome } \\
\text { expectations, educational plans, and } \\
\text { career expectations. }\end{array}$ & $\begin{array}{l}166 \text { high school sophomores (97 } \\
\text { women and } 69 \text { men) from an urban } \\
\text { high school in a midsized } \\
\text { Midwestern city. The self-identified } \\
\text { racial-ethnic composition of } \\
\text { participants was } 129 \text { European } \\
\text { Americans, } 11 \text { African Americans, } 9 \\
\text { Hispanics, } 10 \text { Asian Americans, and } \\
7 \text { "other." }\end{array}$ \\
\hline $\begin{array}{l}\text { Gushue, G. V., Clarke, C. P., } \\
\text { Pantzer, K. M., \& Scanlan, K. R. } \\
\text { (2006). Self-efficacy, perceptions of } \\
\text { barriers, vocational identity, and the } \\
\text { career exploration behavior of } \\
\text { Latino/a high school students. The } \\
\text { Career Development Quarterly, } \\
\text { 54(4), 307-317. }\end{array}$ & $\begin{array}{l}\text { This study explored whether social } \\
\text { cognitive variables (i.e., career } \\
\text { decision-making self-efficacy and } \\
\text { perceptions of barriers) are related } \\
\text { to vocational identity and career } \\
\text { exploration behaviors (i.e., the } \\
\text { outcome variables). }\end{array}$ & $\begin{array}{l}128 \text { urban Latino/a high school } \\
\text { students. }\end{array}$ \\
\hline $\begin{array}{l}\text { Soria, K. M., Roberts, J. E., \& } \\
\text { Reinhard, A. P. (2015). First-year } \\
\text { college students' strengths }\end{array}$ & $\begin{array}{l}\text { This study examined how enhancing } \\
\text { first-year college students'strengths } \\
\text { awareness is related to their }\end{array}$ & $\begin{array}{l}\text { All first-year students at the } \\
\text { institution studied ( } n=779 \text { ) were } \\
\text { offered the Clifton StrengthsFinder }\end{array}$ \\
\hline
\end{tabular}


Journal of Youth Development | http://jyd.pitt.edu/ | Vol. 15 Issue 6 DOI 10.5195/jyd.2020.832

Enhancing College and Career Readiness

\begin{tabular}{|l|l|l|}
\hline $\begin{array}{l}\text { awareness and perceived leadership } \\
\text { development. Journal of Student } \\
\text { Affairs Research and Practice, } \\
\text { 52(1), 89-103. }\end{array}$ & perceived leadership development. & $\begin{array}{l}\text { assessment and strengths-related } \\
\text { programming during their freshman } \\
\text { year. }\end{array}$ \\
\hline $\begin{array}{l}\text { Shushok Jr, F., \& Hulme, E. (2006). } \\
\text { What's right with you: Helping } \\
\text { students find and use their personal } \\
\text { strengths. About Campus, 11(4), 2- } \\
\text { 8. }\end{array}$ & $\begin{array}{l}\text { The authors explored literature } \\
\text { related to intentionally enabling } \\
\text { students to identify, understand, } \\
\text { and leverage their talents, passions, } \\
\text { and strengths allows their unique } \\
\text { genius to emerge and sets them on } \\
\text { a course for success. }\end{array}$ & N/A \\
\hline
\end{tabular}

Table A2. Peer-Reviewed Literature on Behavioral Skills $(n=13)$

\begin{tabular}{|c|c|c|}
\hline Article & Study description & Sample \\
\hline \multicolumn{3}{|c|}{ LITERATURE DESCRIBING GRIT } \\
\hline $\begin{array}{l}\text { Bashant, J. (2014). Developing grit in } \\
\text { our students: Why grit is such a } \\
\text { desirable trait, and practical } \\
\text { strategies for teachers and schools. } \\
\text { Journal for Leadership and } \\
\text { Instruction, 13(2), 14-17. }\end{array}$ & $\begin{array}{l}\text { Examines whether someone can learn to } \\
\text { have grit and whether you can teach grit. }\end{array}$ & N/A \\
\hline $\begin{array}{l}\text { Gerhards, L., \& Gravert, C. (2015). } \\
\text { Grit trumps talent? An experimental } \\
\text { approach. }\end{array}$ & $\begin{array}{l}\text { This study developed and tested an } \\
\text { experimental real-effort task which elicits } \\
\text { grit in an incentivized decision making } \\
\text { setting (via a computerized task) rather } \\
\text { than by using a self-report scale in a } \\
\text { questionnaire. }\end{array}$ & $\begin{array}{l}62 \text { undergraduate students } \\
\text { from Aarhus University }\end{array}$ \\
\hline $\begin{array}{l}\text { Duckworth, A. L., Peterson, C., } \\
\text { Matthews, M. D., \& Kelly, D. R. } \\
\text { (2007). Grit: perseverance and } \\
\text { passion for long-term goals. Journal } \\
\text { of Personality and Social Psychology, } \\
\text { 92(6), 1087. }\end{array}$ & $\begin{array}{l}\text { Explored whether grit is associated with } \\
\text { Big Five Conscientiousness and with self- } \\
\text { control, and whether grit is related to IQ. }\end{array}$ & $\begin{array}{l}\text { Educational attainment was } \\
\text { assessed using } 2 \text { samples of } \\
\text { adults ( } n=1,545 \text { and } n= \\
690 \text { ), grade point average } \\
\text { was assessed among Ivy } \\
\text { League undergraduates ( } n \\
=138 \text { ), retention was } \\
\text { assessed in } 2 \text { classes of }\end{array}$ \\
\hline
\end{tabular}


Enhancing College and Career Readiness

\begin{tabular}{|c|c|c|}
\hline & & $\begin{array}{l}\text { United States Military } \\
\text { Academy, West Point, } \\
\text { cadets ( } n=1,218 \text { and } n= \\
1,308) \text {, and ranking in the } \\
\text { National Spelling Bee was } \\
\text { assessed ( } n=175) .\end{array}$ \\
\hline $\begin{array}{l}\text { Eskreis-Winkler, L., Duckworth, A. L., } \\
\text { Shulman, E. P., \& Beal, S. (2014). } \\
\text { The grit effect: Predicting retention in } \\
\text { the military, the workplace, school } \\
\text { and marriage. Frontiers in } \\
\text { Psychology, 5, } 36 .\end{array}$ & $\begin{array}{l}\text { Examined the association between grit } \\
\text { (i.e., passion and perseverance for long- } \\
\text { term goals), other individual difference } \\
\text { variables, and retention in the military, } \\
\text { workplace sales, high school, and } \\
\text { marriage. }\end{array}$ & $\begin{array}{l}\text { Retention was assessed } \\
\text { using soldiers in the Army } \\
\text { Special Operations Forces ( } n \\
=677 \text { ), sales } \\
\text { representatives at } 6 \text { vacation } \\
\text { ownership corporations ( } n= \\
442 \text { ), high school juniors at } \\
98 \text { Chicago Public Schools ( } n \\
=4,813 \text { ), and adults were } \\
\text { assessed for marital } \\
\text { longevity ( } n=6,362) \text {. }\end{array}$ \\
\hline \multicolumn{3}{|c|}{ LITERATURE DESCRIBING MINDFULNESS } \\
\hline $\begin{array}{l}\text { Broderick, P. C., \& Metz, S. (2009). } \\
\text { Learning to BREATHE: A pilot trial of } \\
\text { a mindfulness curriculum for } \\
\text { adolescents. Advances in School } \\
\text { Mental Health Promotion, 2(1), 35- } \\
46 .\end{array}$ & $\begin{array}{l}\text { A pilot trial of Learning to BREATHE, a } \\
\text { mindfulness curriculum for adolescents } \\
\text { created for a classroom setting. The } \\
\text { primary goal of the program is to support } \\
\text { the development of emotion regulation } \\
\text { skills through the practice of mindfulness } \\
\text { (i.e., intentional, non-judgmental } \\
\text { awareness of present-moment } \\
\text { experience). }\end{array}$ & $\begin{array}{l}120 \text { seniors (average age } \\
17.4 \text { years) from a private } \\
\text { Catholic girls' school in } \\
\text { Pennsylvania participated as } \\
\text { part of their health } \\
\text { curriculum. }\end{array}$ \\
\hline $\begin{array}{l}\text { Mendelson, T., Greenberg, M. T., } \\
\text { Dariotis, J. K., Gould, L. F., Rhoades, } \\
\text { B. L., \& Leaf, P. J. (2010). Feasibility } \\
\text { and preliminary outcomes of a } \\
\text { school-based mindfulness } \\
\text { intervention for urban youth. Journal } \\
\text { of Abnormal Child Psychology, 38(7), } \\
\text { 985-994. }\end{array}$ & $\begin{array}{l}\text { This study assessed the feasibility, } \\
\text { acceptability, and preliminary outcomes of } \\
\text { a school-based mindfulness and yoga } \\
\text { intervention among urban youth. }\end{array}$ & $\begin{array}{l}\text { Four urban public schools in } \\
\text { Baltimore City elementary } \\
\text { schools were randomized to } \\
\text { an intervention or wait-list } \\
\text { control condition ( } n=974^{\text {th }} \\
\text { and } 5^{\text {th }} \text { graders, } 60.8 \% \\
\text { female). }\end{array}$ \\
\hline Gockel, A. (2015). Teaching & This article is a teaching note and & $\mathrm{N} / \mathrm{A}$ \\
\hline
\end{tabular}




\section{Enhancing College and Career Readiness}

\begin{tabular}{l|l}
$\begin{array}{l}\text { Note-Practicing Presence: A } \\
\text { Curriculum for Integrating }\end{array}$ & $\begin{array}{l}\text { introduces a curriculum for integrating } \\
\text { mindfulness training into a foundational } \\
\text { Mindfulness Training into Direct } \\
\text { Practice Instruction. Journal of Social } \\
\text { Work Education, 51(4), 682-690. }\end{array}$ \\
\hline
\end{tabular}

\section{LITERATURE DESCRIBING SELF-ADVOCACY \& SELF-DETERMINATION}

Anctil, T. M., Ishikawa, M. E., \&

Scott, A. T. (2008). Academic identity

development through self-

determination: Successful college

students with learning disabilities.

Career Development for Exceptional

Individuals, 31(3), 164-174.
This study provides a model of academic

identity development for college students

with learning disabilities using self-

determination themes (i.e., persistence,

competence, career decision making, and self-realization).
Nineteen self-determined

and high-achieving college

students with documented

learning disabilities who

were receiving academic

accommodations

from the disability resource

center at a large university

in the Northwest region of

the United States.
Milsom, A., Akos, P., \& Thompson, M.

(2004). A psychoeducational group approach to postsecondary transition planning for students with learning disabilities. The Journal for Specialists in Group Work, 29(4), 395-411.

Mishna, F., Muskat, B., Farnia, F., \& Wiener, J. (2011). The effects of a school-based program on the reported self-advocacy knowledge of students with learning disabilities. Alberta Journal of Educational Research, 57(2), 185-203.

Sebag, R. (2010). Behavior management through self-advocacy: A strategy for secondary students
This article describes a psychoeducational group model designed to increase disability self-awareness, increase postsecondary education knowledge, and promote self-advocacy skills for students with learning disabilities.

This school-based study examined selfreported self-advocacy knowledge of middle school students with learning disabilities.

This article described the self-advocacy behavior management (SABM) model.
68 students (50 boys, 18 girls in grades 6-8 across seven urban schools), their parents, and their teachers were studied. Eighteen (26\%) were native speakers of English. All participating students were diagnosed with a learning disability and were received special education services.

N/A 
Journal of Youth Development | http://jyd.pitt.edu/ | Vol. 15 Issue 6 DOI 10.5195/jyd.2020.832

Enhancing College and Career Readiness

\begin{tabular}{|c|c|c|}
\hline $\begin{array}{l}\text { with learning disabilities. Teaching } \\
\text { Exceptional Children, 22-29. }\end{array}$ & & \\
\hline $\begin{array}{l}\text { Sinclair, J., Bromley, K.W., \& } \\
\text { Shogren, K.A. (2017). An analysis of } \\
\text { motivation in three self- } \\
\text { determination curricula. Career } \\
\text { Development and Transition for } \\
\text { Exceptional Individuals, 40(3), 175- } \\
185 .\end{array}$ & $\begin{array}{l}\text { The authors reviewed three motivational } \\
\text { theories: (contextual theory, self- } \\
\text { determination theory, achievement goal } \\
\text { theory) and three self-determination } \\
\text { curricula (Steps to Self-Determination, } \\
\text { Whose Future Is It Anyway?, and ME! } \\
\text { Lessons for Teaching Self-Awareness and } \\
\text { Self-Advocacy) were analyzed. }\end{array}$ & $\mathrm{N} / \mathrm{A}$ \\
\hline $\begin{array}{l}\text { Downey, J. A. (2008). } \\
\text { Recommendations for fostering } \\
\text { educational resilience in the } \\
\text { classroom. Preventing School Failure: } \\
\text { Alternative Education for Children and } \\
\text { Youth, 53(1), 56-64. }\end{array}$ & $\begin{array}{l}\text { This article reviewed findings from current } \\
\text { educational resilience research that } \\
\text { examined students and teachers in } \\
\text { classroom contexts. }\end{array}$ & N/A \\
\hline
\end{tabular}

Table A3. Peer-Reviewed Literature on College and Career Readiness $(\boldsymbol{n}=17)$

\begin{tabular}{|c|c|c|}
\hline Article & Study description & Sample \\
\hline \multicolumn{3}{|c|}{ LITERATURE DESCRIBING COLLEGE AND CAREER ASPIRATIONS/READINESS } \\
\hline $\begin{array}{l}\text { ACT. (2016). Identifying Skills to } \\
\text { succeed in School, at Work, and in } \\
\text { the "Real World". Iowa City, IA: ACT. }\end{array}$ & $\begin{array}{l}\text { This White Paper identifies the important } \\
\text { of strong academic behaviors for college } \\
\text { and career readiness and success, and } \\
\text { ways teachers, schools, districts, and } \\
\text { states can use the information to enhance } \\
\text { student readiness. }\end{array}$ & N/A \\
\hline $\begin{array}{l}\text { Ali, S. R., \& McWhirter, E. H. (2006). } \\
\text { Rural Appalachian youth's } \\
\text { vocational/educational postsecondary } \\
\text { aspirations: Applying social cognitive } \\
\text { career theory. Journal of Career } \\
\text { Development, 33(2), 87-111. }\end{array}$ & $\begin{array}{l}\text { This study investigates the relationship } \\
\text { between postsecondary aspirations and } \\
\text { vocational/educational self-efficacy } \\
\text { beliefs, outcome expectations, perceived } \\
\text { educational barriers, and sources of } \\
\text { support. }\end{array}$ & $\begin{array}{l}338 \text { (182 male, } 156 \text { female) } \\
11^{\text {th-grade high school }} \\
\text { students drawn from five } \\
\text { high schools in rural } \\
\text { southern Appalachia. }\end{array}$ \\
\hline $\begin{array}{l}\text { Dipeolu, A. O. (2011). College } \\
\text { students with ADHD: Prescriptive } \\
\text { concepts for best practices in career }\end{array}$ & $\begin{array}{l}\text { This article highlights: (a) college and } \\
\text { post college work implications of ADHD } \\
\text { characteristics and (b) effective }\end{array}$ & N/A \\
\hline
\end{tabular}




\section{Enhancing College and Career Readiness}

\begin{tabular}{|c|c|c|}
\hline $\begin{array}{l}\text { development. Journal of Career } \\
\text { Development, 38(5), 408-427. }\end{array}$ & $\begin{array}{l}\text { interventions that counselors can } \\
\text { implement to buttress the career planning } \\
\text { process and post college occupational } \\
\text { success for students with ADHD. }\end{array}$ & \\
\hline $\begin{array}{l}\text { Jepsen, D. A., \& Dickson, G. L. } \\
\text { (2003). Continuity in life-span career } \\
\text { development: Career exploration as a } \\
\text { precursor to career establishment. } \\
\text { The Career Development Quarterly, } \\
\text { 51(3), 217-233. }\end{array}$ & $\begin{array}{l}\text { The authors examined continuity in career } \\
\text { development from adolescence to mid } \\
\text { adulthood by testing whether early task- } \\
\text { coping activity predicts later task-coping } \\
\text { activity. }\end{array}$ & $\begin{array}{l}146 \text { rural high school } \\
\text { graduates }\end{array}$ \\
\hline $\begin{array}{l}\text { Morningstar, M., Lombardi, A., } \\
\text { Fowler, C.H., \& Test, D.W. (2017). A } \\
\text { college and career readiness } \\
\text { framework for secondary students } \\
\text { with disabilities. Career Development } \\
\text { and Transition for Exceptional } \\
\text { Individuals, 40(2), 79-91. }\end{array}$ & $\begin{array}{l}\text { This article proposed an organizing } \\
\text { framework of college and career readiness } \\
\text { for secondary students with disabilities, } \\
\text { which was developed based on a } \\
\text { synthesis of extant research articulating } \\
\text { student success. }\end{array}$ & $\begin{array}{l}22 \text { participants representing } \\
17 \text { states were invited and } \\
\text { participated in one of two } \\
\text { focus groups. Participants } \\
\text { were state education agency } \\
\text { representatives. }\end{array}$ \\
\hline $\begin{array}{l}\text { Nota, L., Ginevra, M. C., \& Carrieri, L. } \\
\text { (2010). Career interests and self- } \\
\text { efficacy beliefs among young adults } \\
\text { with an intellectual disability. Journal } \\
\text { of Policy and Practice in Intellectual } \\
\text { Disabilities, 7(4), 250-260. }\end{array}$ & $\begin{array}{l}\text { The study examined whether people with } \\
\text { Intellectual Disability have interests and } \\
\text { self-efficacy beliefs in less complex } \\
\text { occupations, and whether self-efficacy } \\
\text { beliefs can predict career interests, similar } \\
\text { to results observed with individuals } \\
\text { without Intellectual Disability. The study } \\
\text { also investigated differences associated } \\
\text { with Intellectual Disability level and with } \\
\text { gender. }\end{array}$ & $\begin{array}{l}129 \text { young adults with } \\
\text { Intellectual Disability. }\end{array}$ \\
\hline $\begin{array}{l}\text { Savickas, M. L. (2011). Constructing } \\
\text { careers: Actor, agent, and author. } \\
\text { Journal of Employment Counseling, } \\
\text { 48(4), 179-181. }\end{array}$ & $\begin{array}{l}\text { This article is a description of career } \\
\text { construction theory. }\end{array}$ & $\mathrm{N} / \mathrm{A}$ \\
\hline $\begin{array}{l}\text { Suh, S., \& Suh, J. (2006). Educational } \\
\text { engagement and degree attainment } \\
\text { among high school dropouts. } \\
\text { Educational Research Quarterly, } \\
29(3), 11 .\end{array}$ & $\begin{array}{l}\text { This study investigates the relationship } \\
\text { between educational engagement and } \\
\text { high school degree attainment among } \\
\text { school dropouts. }\end{array}$ & $\begin{array}{l}1,430 \text { dropouts, } 963 \text { youths } \\
\text { successfully completed high } \\
\text { school education through } \\
\text { either receiving a diploma or } \\
\text { obtaining a GED. The final }\end{array}$ \\
\hline
\end{tabular}




\section{Enhancing College and Career Readiness}

\begin{tabular}{|c|c|c|}
\hline & & $\begin{array}{l}\text { dropouts (or permanent } \\
\text { dropouts) are } 467 \text { youths } \\
\text { who were neither working } \\
\text { for nor ever attained a high } \\
\text { school diploma or its } \\
\text { equivalency. The total } \\
\text { sample was composed of } \\
678 \text { males and } 752 \text { females } \\
\text { (890 were white, } 170 \text { were } \\
\text { black, } 299 \text { were Hispanic } \\
\text { Origin, } 28 \text { were American } \\
\text { Indian or Alaskan Native, } 34 \\
\text { were Asian or Pacific } \\
\text { Islander, and } 9 \text { were missing } \\
\text { or more than one race). }\end{array}$ \\
\hline \multicolumn{3}{|c|}{ LITERATURE DESCRIBING COLLEGE AND CAREER/ADULT SUCCESS } \\
\hline $\begin{array}{l}\text { Burgstahler, S. (2001). A } \\
\text { collaborative model to promote } \\
\text { career success for students with } \\
\text { disabilities. Journal of Vocational } \\
\text { Rehabilitation, } 16(3,4), 209-215 .\end{array}$ & $\begin{array}{l}\text { University of Washington conducted a 3- } \\
\text { year project (DO-IT program) to assist } \\
\text { students with disabilities head toward } \\
\text { successful careers using a team from } \\
\text { precollege and postsecondary educational } \\
\text { institutions, parents, mentors, employers, } \\
\text { and community service providers. }\end{array}$ & $\begin{array}{l}60 \text { high school and } \\
\text { postsecondary students with } \\
\text { disabilities completed } 104 \\
\text { placements over the three- } \\
\text { year grant period. }\end{array}$ \\
\hline $\begin{array}{l}\text { O'Connor, M., Sanaon, A. ,Hawkins, } \\
\text { M., Letcher, P., Toumbourou. J. } \\
\text { Smart, D., Vassallo, S., \& Olsson, C. } \\
\text { (2011). Predictors of positive } \\
\text { development in emerging adulthood. } \\
\text { Journal of Youth and Adolescence. } \\
\text { 40, 860-874. }\end{array}$ & $\begin{array}{l}\text { This study examined child and adolescent } \\
\text { precursors of positive functioning in } \\
\text { emerging adulthood, including individual } \\
\text { characteristics, relationship factors, and } \\
\text { connections to the community, using a } \\
\text { multidimensional positive development } \\
\text { measure at 19-20 years. }\end{array}$ & $\begin{array}{l}511 \text { males and } 647 \text { females } \\
\text { who were participants in the } \\
\text { Australian Temperament } \\
\text { Project, a population based } \\
\text { longitudinal study that has } \\
\text { followed young people's } \\
\text { psychosocial adjustment } \\
\text { from infancy to early } \\
\text { adulthood. }\end{array}$ \\
\hline $\begin{array}{l}\text { Patton, W., Creed, P. A., \& Muller, J. } \\
\text { (2002). Career maturity and well- } \\
\text { being as determinants of } \\
\text { occupational status of recent school }\end{array}$ & $\begin{array}{l}\text { This study explored whether age, gender, } \\
\text { data on career maturity, psychological } \\
\text { wellbeing, and school achievement } \\
\text { reported while still at school could be }\end{array}$ & $\begin{array}{l}254 \text { Australian high school } \\
\text { students in grade } 12 \text {. }\end{array}$ \\
\hline
\end{tabular}


Enhancing College and Career Readiness

\begin{tabular}{|c|c|c|}
\hline $\begin{array}{l}\text { leavers: A brief report of an } \\
\text { Australian study. Journal of } \\
\text { Adolescent Research, 17(4), 425-435. }\end{array}$ & $\begin{array}{l}\text { identified as predictors of occupational } \\
\text { status. }\end{array}$ & \\
\hline $\begin{array}{l}\text { Powers, L. E., Geenen, S., Powers, J., } \\
\text { Pommier-Satya, S., Turner, A., } \\
\text { Dalton, L. D., ... \& Swank, P. (2012). } \\
\text { My Life: Effects of a longitudinal, } \\
\text { randomized study of self- } \\
\text { determination enhancement on the } \\
\text { transition outcomes of youth in foster } \\
\text { care and special education. Children } \\
\text { and Youth Services Review, 34(11), } \\
\text { 2179-2187. }\end{array}$ & $\begin{array}{l}\text { This study explored whether the TAKE } \\
\text { CHARGE model (i.e., individual weekly } \\
\text { coaching sessions for youth in the } \\
\text { application of self-determination skills; } \\
\text { and quarterly workshops for youth with } \\
\text { young adult mentors who were formerly } \\
\text { in foster care and now were 3-4 years } \\
\text { older and attending college, working } \\
\text { successfully in a career area of who had } \\
\text { overcome barriers to transition success) } \\
\text { increased self-determination in a sample } \\
\text { of youth with disabilities who also were in } \\
\text { foster care. }\end{array}$ & $\begin{array}{l}69 \text { youth, ages } 16.5 \text { to } 17.5 \\
\text { who are both in foster care } \\
\text { and special education. }\end{array}$ \\
\hline $\begin{array}{l}\text { Rogers, M. E., \& Creed, P. A. (2011). } \\
\text { A longitudinal examination of } \\
\text { adolescent career planning and } \\
\text { exploration using a social cognitive } \\
\text { career theory framework. Journal of } \\
\text { Adolescence, 34(1), 163-172. }\end{array}$ & $\begin{array}{l}\text { This study tested the correlates of career } \\
\text { planning and exploration using cross- } \\
\text { sectional, and then longitudinal data }\end{array}$ & $\begin{array}{l}631 \text { Australian high school } \\
\text { students (mostly middle } \\
\text { class and Caucasian) in } \\
\text { grades } 10-12 \text {. }\end{array}$ \\
\hline $\begin{array}{l}\text { Santilli, S., Nota, L., Ginevra, M. C., \& } \\
\text { Soresi, S. (2014). Career adaptability, } \\
\text { hope and life satisfaction in workers } \\
\text { with intellectual disability. Journal of } \\
\text { Vocational Behavior, } 85(1), 67-74 .\end{array}$ & $\begin{array}{l}\text { This study examined two variables (i.e., } \\
\text { career adaptability and hope) relevant to } \\
\text { coping with the current work context and } \\
\text { their role in affecting life satisfaction. A } \\
\text { partial mediational model between career } \\
\text { adaptability and life satisfaction, through } \\
\text { agency and pathway (hope), was tested. }\end{array}$ & $\begin{array}{l}120 \text { ( } 60 \text { women and } 60 \\
\text { men) adult workers with } \\
\text { mild intellectual disability. }\end{array}$ \\
\hline $\begin{array}{l}\text { Savickas, M.L. (2012). Life design: A } \\
\text { paradigm for career intervention in } \\
\text { the } 21^{\text {st }} \text { century. Journal of } \\
\text { Counseling \& Development, 90, 13- } \\
19 .\end{array}$ & $\begin{array}{l}\text { This article describes how life design } \\
\text { interventions constructs career through } \\
\text { small stories, reconstructs the stories into } \\
\text { a life portrait, and co-constructs intentions } \\
\text { that advance the career story into a new } \\
\text { episode. }\end{array}$ & $\mathrm{N} / \mathrm{A}$ \\
\hline Savickas, M. L., Nota, L., Ross & This article presents a counseling model. & $\mathrm{N} / \mathrm{A}$ \\
\hline
\end{tabular}


Journal of Youth Development | http://jyd.pitt.edu/ | Vol. 15 Issue 6 DOI 10.5195/jyd.2020.832

Enhancing College and Career Readiness

\begin{tabular}{|c|c|c|}
\hline $\begin{array}{l}\text { Dauwalder, J. P., Duarte, M. E., } \\
\text { Guichard, J., Soresi, S., Van } \\
\text { Esbroeck, R., \& Van Vianen, A. E. } \\
\text { (2009). Life designing: A paradigm } \\
\text { for career construction in the } 21^{\text {st }} \\
\text { century. Journal of Vocational } \\
\text { Behavior, 75(3), 239-250. }\end{array}$ & & \\
\hline $\begin{array}{l}\text { Savickas, M. L., \& Porfeli, E. J. } \\
\text { (2012). Career Adapt-Abilities Scale: } \\
\text { Construction, reliability, and } \\
\text { measurement equivalence across } 13 \\
\text { countries. Journal of Vocational } \\
\text { Behavior, } \\
80(3), 661-673 .\end{array}$ & $\begin{array}{l}\text { Researchers from } 13 \text { countries } \\
\text { collaborated in constructing a } \\
\text { psychometric scale to measure } \\
\text { career adaptability. Based on four pilot } \\
\text { tests, a research version of the proposed } \\
\text { scale consisting } \\
\text { of } 55 \text { items was field tested in } 13 \\
\text { countries. }\end{array}$ & Not specified. \\
\hline
\end{tabular}


Journal of Youth Development | http://jyd.pitt.edu/ | Vol. 15 Issue 6 DOI 10.5195/jyd.2020.832 Enhancing College and Career Readiness

Appendix B

Demographic Information for Three Focus Group Populations: Students, Parents, and Educators

\begin{tabular}{|c|c|c|c|c|c|c|}
\hline & \multicolumn{2}{|c|}{$\begin{array}{l}\text { Students } \\
(n=37)\end{array}$} & \multicolumn{2}{|c|}{$\begin{array}{l}\text { Parents } \\
(n=18)\end{array}$} & \multicolumn{2}{|c|}{$\begin{array}{l}\text { Educators } \\
(n=48)\end{array}$} \\
\hline & $n$ & Percent & $n$ & Percent & $n$ & Percent \\
\hline \multicolumn{7}{|l|}{ Grade } \\
\hline 9 & 7 & 18.9 & & & & \\
\hline 10 & 5 & 13.5 & & & & \\
\hline 11 & 13 & 35.1 & & & & \\
\hline 12 & 12 & 32.4 & & & & \\
\hline \multicolumn{7}{|l|}{ Gender } \\
\hline Female & 15 & 39.5 & 15 & 83.3 & 31 & 64.6 \\
\hline Male & 22 & 59.5 & 3 & 16.7 & 17 & 35.4 \\
\hline \multicolumn{7}{|l|}{ Hispanic or Latino } \\
\hline Yes & 17 & 45.9 & 3 & 16.7 & 3 & 6.3 \\
\hline No & 20 & 54.1 & 15 & 83.3 & 45 & 93.8 \\
\hline \multicolumn{7}{|l|}{ Race/ethnicity } \\
\hline White & 15 & 40.5 & 14 & 77.7 & 41 & 85.4 \\
\hline African American & 5 & 13.5 & 2 & 11.1 & 1 & 2.1 \\
\hline Asian American & & & & & 1 & 2.1 \\
\hline American Indian or Alaskan Native & 1 & 2.7 & & & 1 & 2.1 \\
\hline More than one race & 3 & 8.1 & 1 & 5.6 & & \\
\hline Native Hawaiian or other Pacific Islander & & & & & 1 & 2.1 \\
\hline Other & 11 & 29.7 & 1 & 5.6 & 1 & 2.1 \\
\hline Missing & 2 & 5.4 & & & 2 & 4.1 \\
\hline On an IEP or 504 plan & 14 & 37.8 & & & & \\
\hline \multicolumn{7}{|l|}{ Role (educator only) } \\
\hline Teacher & & & & & 19 & 39.6 \\
\hline Counselor & & & & & 7 & 14.6 \\
\hline Instructional aide & & & & & 4 & 8.3 \\
\hline Transition specialist & & & & & 4 & 8.3 \\
\hline Other & & & & & 14 & 29.2 \\
\hline
\end{tabular}


Journal of Youth Development ｜ http://jyd.pitt.edu/ | Vol. 15 Issue 6 DOI 10.5195/jyd.2020.832

Enhancing College and Career Readiness

\begin{tabular}{|c|c|c|}
\hline \multicolumn{3}{|l|}{ Education level (parents only) } \\
\hline $10^{\text {th }}$ or $11^{\text {th }}$ grade & 1 & 5.6 \\
\hline High school graduate & 6 & 33.3 \\
\hline Partial college & 6 & 33.3 \\
\hline $\begin{array}{l}\text { College, university or community college } \\
\text { graduate }\end{array}$ & 3 & 16.7 \\
\hline Graduate or professional training & 2 & 11.1 \\
\hline
\end{tabular}

